\title{
MANUFACTURING OF VALVE BRIDGE COMPONENT UTILIZING LEAN ALLOYED POWDERS AND VACUUM SINTERING
}

\author{
R. Shvab, M. V. Sundaram, H. Karlsson, D. Chasoglou, S. Berg, E. Hryha, L. Nyborg
}

\begin{abstract}
Increasing the application area of powder metallurgy (PM) steels for manufacturing of high-performance structural components results in material saving, reduction in energy consumption, etc. In this study, feasibility of the manufacturing of valve bridge component for heavy duty engine utilizing lean alloyed powders and novel vacuum sintering approach, followed by low pressure carburizing, is studied. Three low alloyed steel powders were processed by conventional uniaxial pressing and sintering at 1120 and $1250^{\circ} \mathrm{C}$ in industrial vacuum furnace. The components were tested under high cycle fatigue testing, simulating real conditions of operation. Fatigue properties did not show significant dependence on the sintering temperature and were comparable to currently used reference cast material. Fracture surfaces of broken samples were analyzed to detect crack initiations and fracture mechanisms as well as quality of sintering. Results showed preferentially ductile failure, well developed sintering necks and clean pore surfaces, indicating good sintering. Tested material in combination with novel vacuum sintering process show to be an attractive alternative for manufacturing of this type of components for heavy duty engine applications.
\end{abstract}

Keywords: Powder metallurgy, low alloyed steel, high cycle fatigue, fracture, sintering, low pressure carburizing.

\section{INTRODUCTION}

Powder metallurgy is referred to be a cost efficient and sustainable manufacturing processes for near-net-shaped production [1]. It covers huge variety of applications - from structural components to biomedical applications [2-5]. PM steels have become the most significant products of PM technology today and account for more than $80 \%$ of the total volume of all materials produced. Improvement in the quality of powder, development of new alloy systems and sophistication in the processing techniques have extended the range of applications for sintered ferrous and ferrous alloy parts [6]. Due to the high surface area present for the case of PM steel powders, they are subject to significant risk of oxidation. For this reason, traditionally, alloying elements such as $\mathrm{Cu}$, Mo and Ni have been used as they are easily reducible during conventional sintering process.

Ruslan Shvab, Maheswaran Vattur Sundaram, Eduard Hryha, Lars Nyborg: Department of Industrial and Materials Science, Chalmers University of Technology, Rännvagen 2A, 41296 Göteborg, Sweden

Henrik Karlsson: Volvo Group Trucks Technology, Göteborg, Sweden

Dimitris Chasoglou, Sigurd Berg: Höganäs AB, Höganäs, Sweden 
However, utilizing $\mathrm{Cr}$ as an alloying element becomes more interesting nowadays. One of the main advantages is the economic benefit since $\mathrm{Cu}$ and $\mathrm{Ni}$ are significantly more expensive than $\mathrm{Cr}$. Furthermore, $\mathrm{Cr}$ has higher hardenability which makes it suitable for high performance applications and sinter-hardening [7]. The major challenge concerning usage of $\mathrm{Cr}$ as an alloying element is its high oxygen affinity, which put strict demands on processing. By prealloying, the activity of chromium can be reduced and for the low levels of chromium, prealloying does not significantly degrade compressibility of the powders [8]. Taking into account the advantages of low Cr alloyed PM steels, they become more and more interesting for high performance applications. On the other hand, the mechanical properties depend very much on the microstructure, density and pores characteristics [912]. It gives some freedom and possibility to tune the PM material properties in the required way. Usage of different heat treatment processes including low pressure carburization (LPC) and gas quenching [13], as a separate process or integrated in modern vacuum furnaces, is another advantage of using PM manufacturing process.

\section{MATERIALS AND METHODS}

Two commercial alloys, namely Astaloy CrA and Distaloy DH, and experimental low $\mathrm{Cr}$ alloyed powder were used as based materials in this investigation. All powders were supplied by Höganäs AB, Sweden. Powders were admixed with natural graphite (UF4, Kropfmühl) and lubricant (Lube E). Composition of the respective mixes is summarized in Table 1.

Table 1. Composition of powder mixes.

\begin{tabular}{|c|c|c|c|c|}
\hline Base powder & $\mathrm{Cu}$, wt.\% & Ni, wt.\% & C, wt.\% & Lube E, wt.\% \\
\hline Low Cr alloyed & 2 & - & 0.65 & 0.6 \\
\hline Astaloy CrA (Fe-1.8Cr) & - & 1 & 0.45 & 0.6 \\
\hline Distaloy DH (Fe-2Cu-1.5Mo) & - & - & 0.6 & 0.6 \\
\hline
\end{tabular}

Abovementioned powder mixes were pressed into cylindrical blocks, vacuum sintered and machined to receive a valve bridge component shape, see Figure 1.

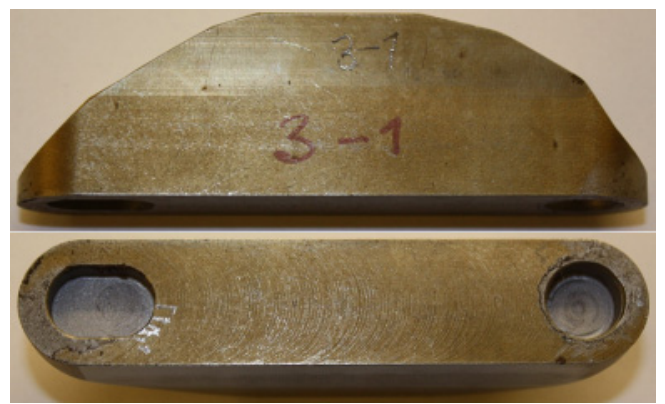

Fig.1. „Side“ (up) and „bottom“ (down) view of the valve bridge component prototype for heavy duty engine application.

Vacuum sintering followed by the low pressure carburizing was done in a two chamber furnace with high pressure gas quench, Fulgura Duo by ECM Technologies. Sintering was performed at both 1120 and $1250^{\circ} \mathrm{C}$ for $30 \mathrm{~min}$ for all the investigated 
materials. Acetylene diluted with nitrogen was used as carburizing gas and the samples were quenched with nitrogen under 20 bars pressure.

The high cycle fatigue properties of the valve bridges were tested in the RUMUL vibrophore machine. Loads were measured with the built in load cell. The fixture consisted of two valve shafts cut and fitted into a $25 \mathrm{~mm}$ thick steel plate. The diameter of the valve shafts were $10 \mathrm{~mm}$. A flat wedge with a rounded top was used for load application in the middle between the valve shafts to create a 3 point bending load, see Figure 2. Fatigue testing frequency was $112 \mathrm{~Hz}$. The cycling was carried out until the frequency dropped $3 \mathrm{~Hz}$.

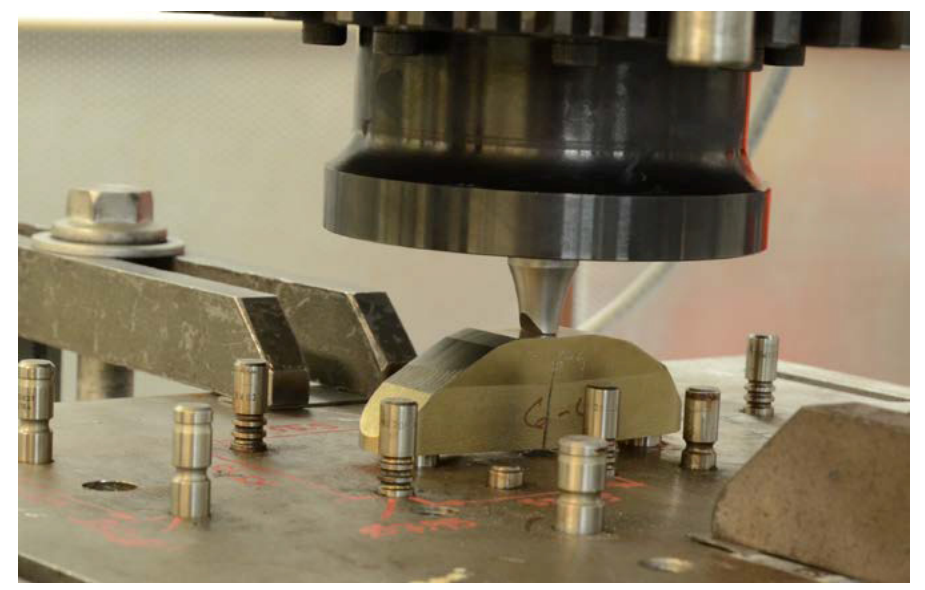

Fig.2. High cycle fatigue testing set-up.

Materials after testing were analysed by light optical microscopy (Leitz DMRX) to obtain representative microstructures. Fracture surfaces of broken samples were analysed by stereo microscope SteREO Discovery.V20 and scanning electron microscope LEO Gemini 1550 (LEO GmbH, Oberkochen, Germany) in order to detect crack initiations, quality of sintering and fracture mechanisms.

\section{RESULTS AND DISCUSSION}

\section{High cycle fatigue testing}

High cycle fatigue tests were performed at Volvo Group Trucks Technology, Göteborg, Sweden, to simulate the real operating conditions for investigated materials. Preliminary tests showed preferential fracture of the samples in the hole, due to a sharp corner inside the hole induced by machining. To avoid such failure, grinding and radii shot peening was applied. Further tests showed fracturing in the middle part of the sample, see Figure 2. Results presented in Figure 3 give the overview of the fatigue behaviour of new investigated materials prepared by powder metallurgy route in comparison to currently used cast material. Results showed that low pressure carburised Astaloy CrA material has strength similar to the reference material. Moreover, Astaloy CrA samples did not break even after $10^{7}$ cycles. At the same time, low $\mathrm{Cr}$ alloyed material and Distaloy $\mathrm{DH}$ showed lower fatigue strength than reference material. No significant influence of sintering temperature on the fatigue strength of materials was revealed by fatigue tests. Surface hardness measured in the area of loading application showed slightly higher values for 
materials sintered at $1250^{\circ} \mathrm{C}$ in comparison to ones sintered at $1120^{\circ} \mathrm{C}$, see Table 2 . Surface hardness of Astaloy $\mathrm{CrA}$ and low $\mathrm{Cr}$ alloyed materials are comparable to each other, while Distaloy DH has slightly lower values.

Taking to account that prototypes of valve bridge components tested in this study were machined from cylindrical blocks - their geometry, shape and size of the holes, surface hardness and density are not optimized. Further improvement of abovementioned parameters will increase fatigue strength of investigated materials.

Tab. 2. Surface hardness of investigated materials.

\begin{tabular}{|c|c|c|}
\hline Material & Sintering temperature, ${ }^{\circ} \mathrm{C}$ & Surface hardness, HV10 \\
\hline Low Cr alloyed & 1120 & $477 \pm 7$ \\
\hline Low Cr alloyed & 1250 & $506 \pm 28$ \\
\hline Astaloy CrA & 1120 & $467 \pm 20$ \\
\hline Astaloy CrA & 1250 & $505 \pm 32$ \\
\hline Distaloy DH & 1120 & $438 \pm 17$ \\
\hline Distaloy DH & 1250 & $482 \pm 15$ \\
\hline
\end{tabular}

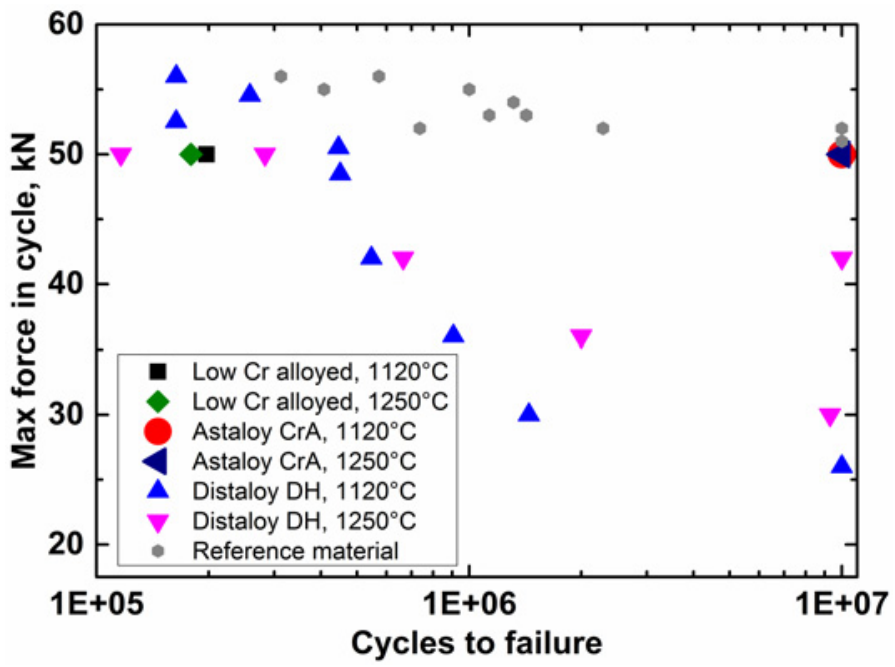

Fig.3. Fatigue tests results for investigated materials in comparison to the reference material.

\section{Metallographic investigation}

The example of pores structure of investigated materials sintered at $1120^{\circ} \mathrm{C}$ presented in the Figure 4. In all cases pores are well distributed in the material. Low $\mathrm{Cr}$ alloyed material contains large pores, most probably due to admixed $\mathrm{Cu}$ powder.

The microstructure of low $\mathrm{Cr}$ alloyed material is mostly martensitic with areas of ferrite and pearlite, see Figure 5.

The microstructure of Astaloy CrA material contains martensite with Ni-rich austenite areas and some bainite, see Figure 6. Areas of austenite and bainite are smaller for material sintered at $1250^{\circ} \mathrm{C}$ due to better diffusion at higher temperature.

In the case of Distaloy DH, the microstructure was martensitic, see Figure 7. 


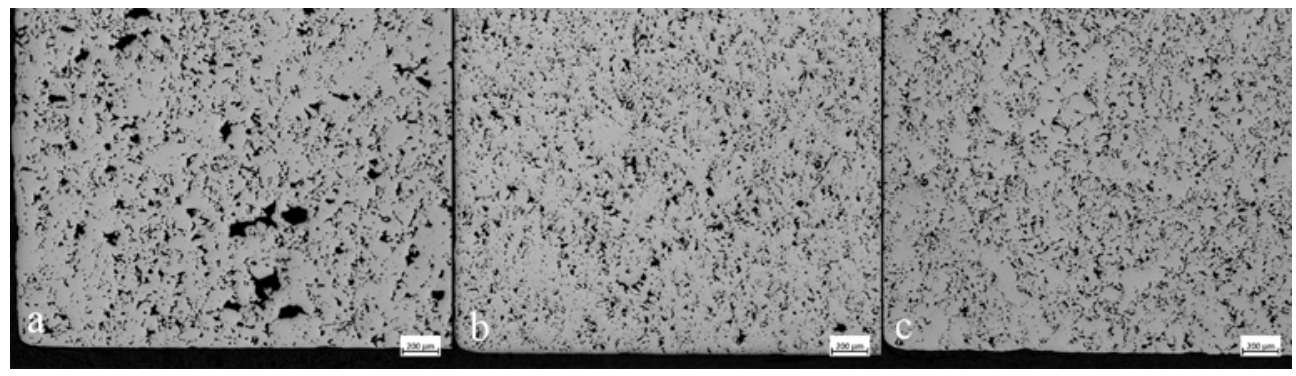

Fig.4. None-etched microstructure of low Cr alloyed steel (a), Astaloy CrA (b) and Distaloy $\mathrm{DH}(\mathrm{c})$ materials sintered at $1120^{\circ} \mathrm{C}$.
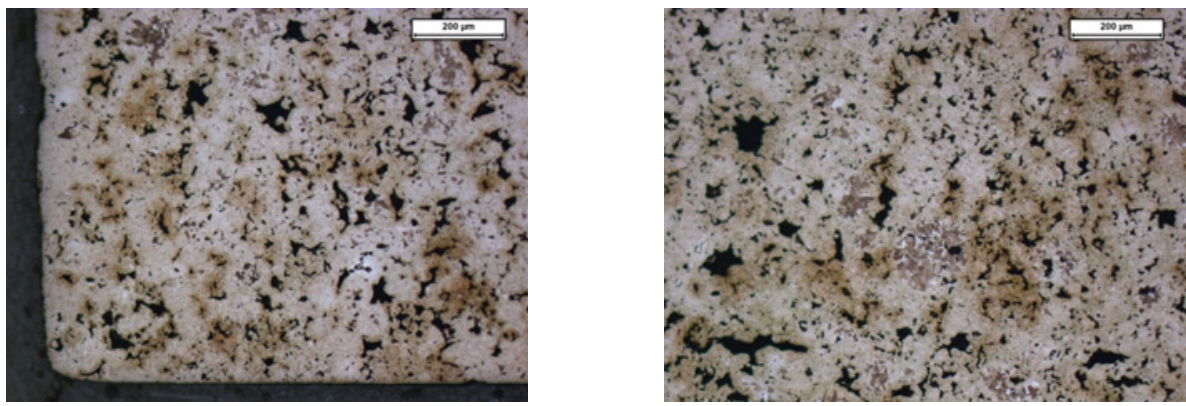

Fig.5. The microstructure of low $\mathrm{Cr}$ alloyed material sintered at $1120^{\circ} \mathrm{C}$.
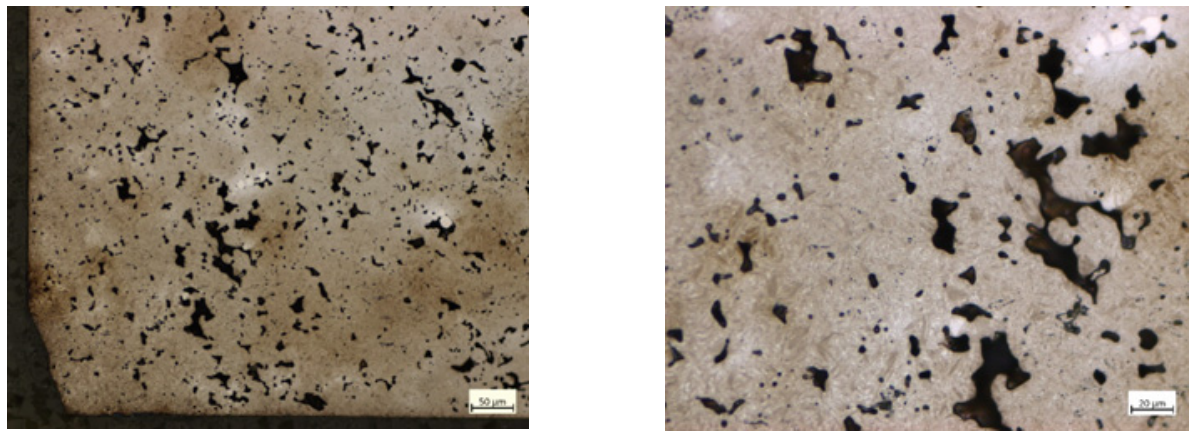

Fig.6. The microstructure of Astaloy $\mathrm{CrA}$ material sintered at $1120^{\circ} \mathrm{C}$.
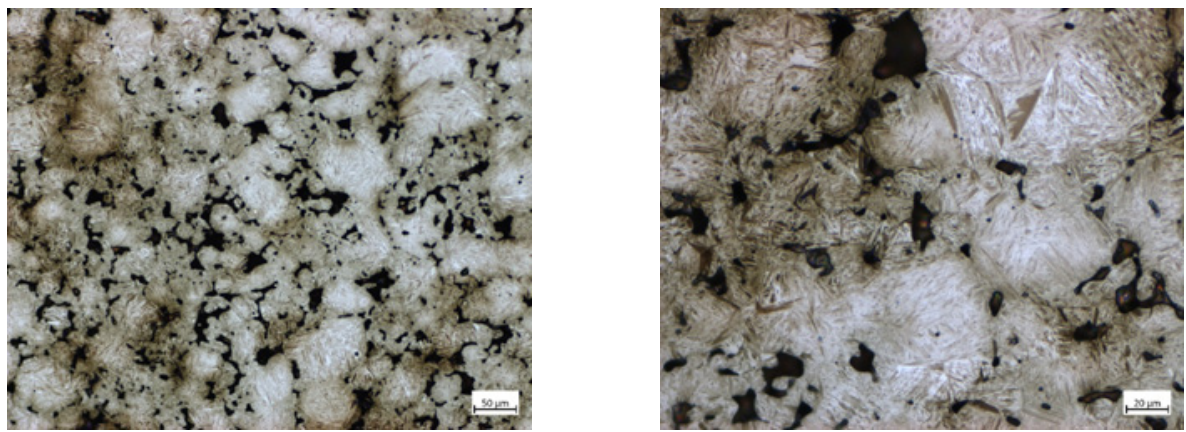

Fig.7. The microstructure of Distaloy DH material sintered at $1120^{\circ} \mathrm{C}$. 


\section{Fracture surface analysis}

In order to find the crack initiation sites, identify the fracture mechanisms and check the quality of the sintering, the fracture surface analysis was performed for the broken samples. In the case of low $\mathrm{Cr}$ alloyed powder sintered at both 1120 and $1250^{\circ} \mathrm{C}$, crack initiations were detected close to the sample surface. For material sintered at $1120^{\circ} \mathrm{C}$ the initiation site was found at the „bottom“ of the sample, see Figure $8 \mathrm{a}$, while for $1250^{\circ} \mathrm{C}$ sintered material it was closer to the ,side“" of the sample, see Figure $8 \mathrm{~b}$.

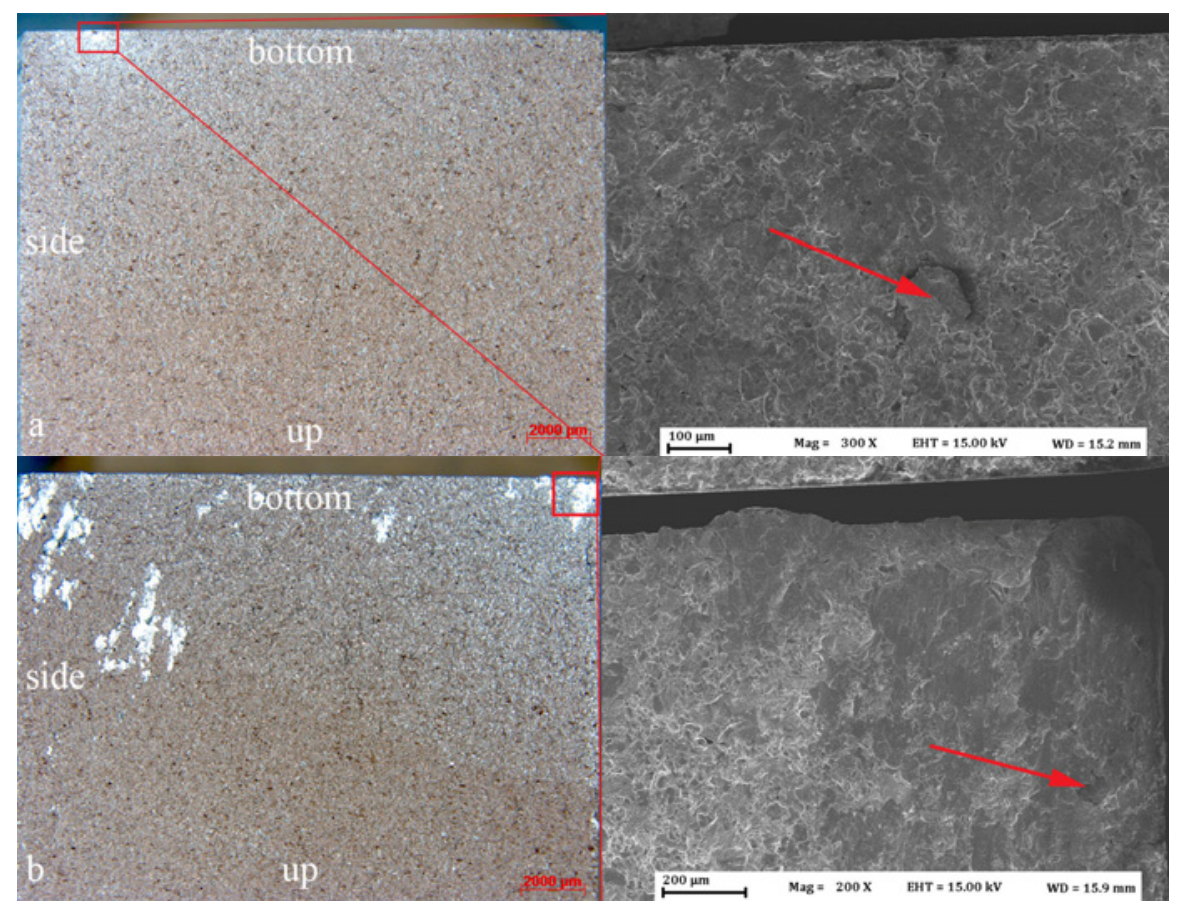

Fig.8. Crack initiations for low $\mathrm{Cr}$ alloyed material samples sintered at a) 1120 , b) $1250^{\circ} \mathrm{C}$.

Inter and transparticle ductile fracture was found to be the main failure mechanism for low $\mathrm{Cr}$ alloyed material sintered at both 1120 and $1250^{\circ} \mathrm{C}$ temperatures, see Figure 9. Some areas with cleavage were also observed. No siginifacant oxide residues were detected, indicating good sintering.

For the valve bridges made of Distaloy DH powder material and sintered at both 1120 and $1250^{\circ} \mathrm{C}$, crack initiation sites were found at the bottom edges of the component, see Figure 10.

Similarly to low $\mathrm{Cr}$ alloyed material, ductile fracure was the main mechanism of failure for Distaloy DH material sintered at both 1120 and $1250^{\circ} \mathrm{C}$ temperatures, see Figure 11. Well developped sintering necks with absence of residual oxides indicate good quality of sintering process.

Since valve bridge components made of Astaloy CrA material did not brake during high cycle fatigue testing, there was no fracture surface available for the investigation. 


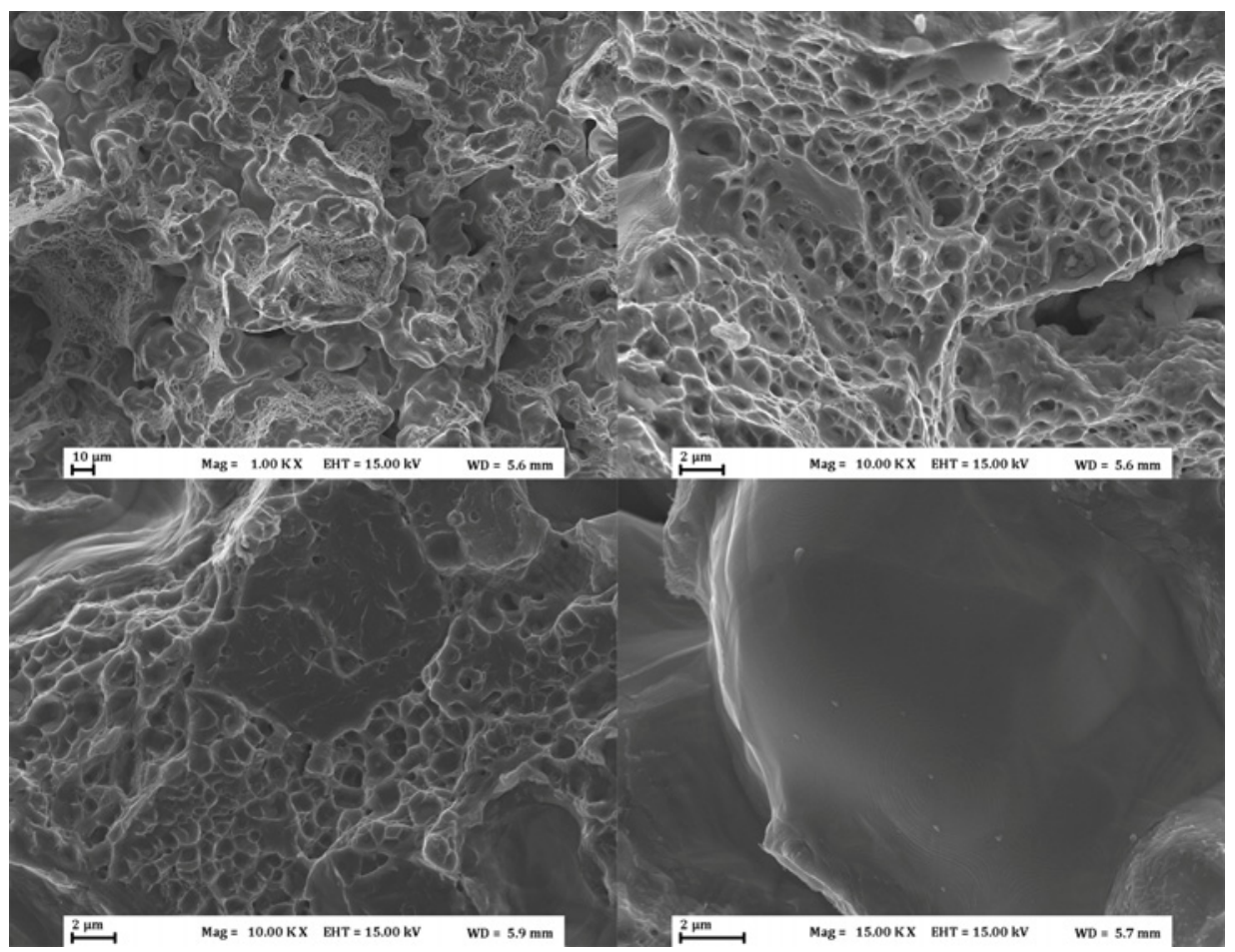

Fig.9. Fracture surface of low $\mathrm{Cr}$ alloyed material sintered at $1120^{\circ} \mathrm{C}$.
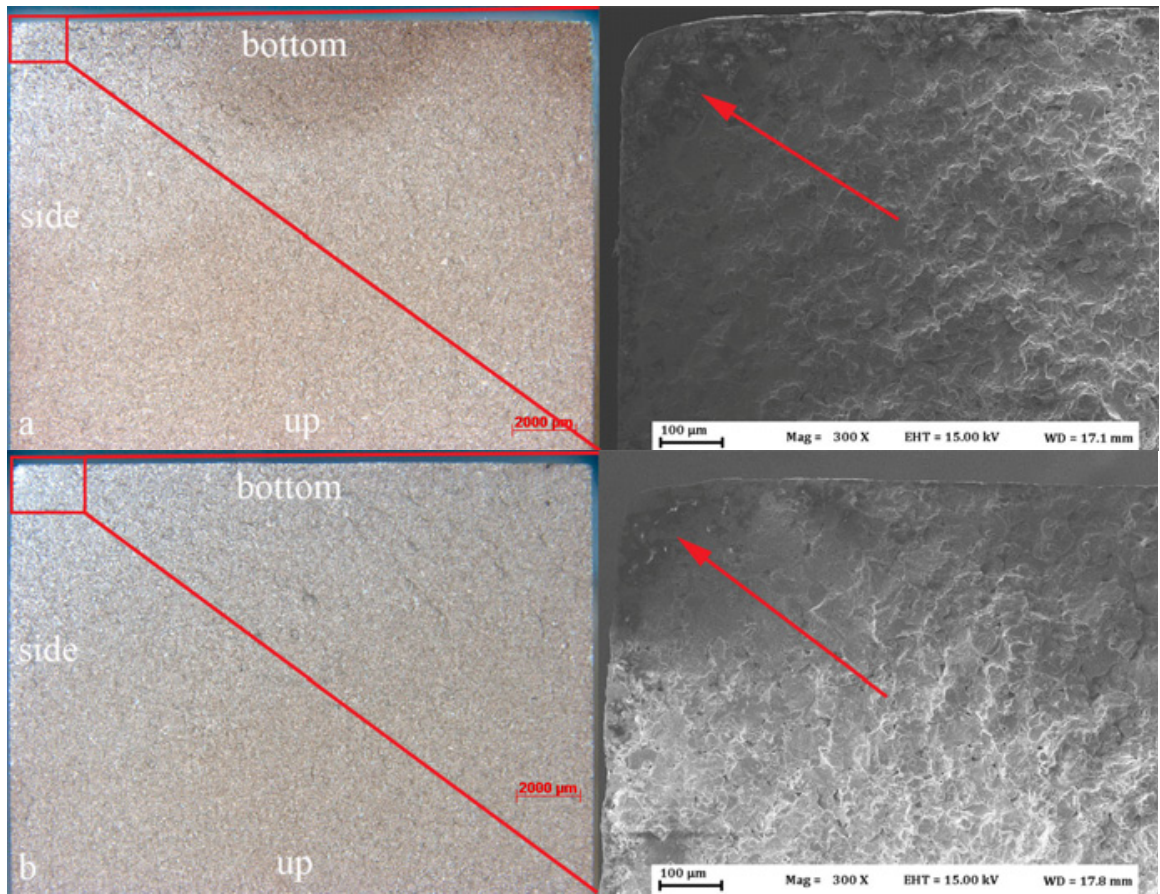

Fig.10. Crack initiations for Distaloy DH powder samples sintered at a) 1120 , b) $1250^{\circ} \mathrm{C}$. 


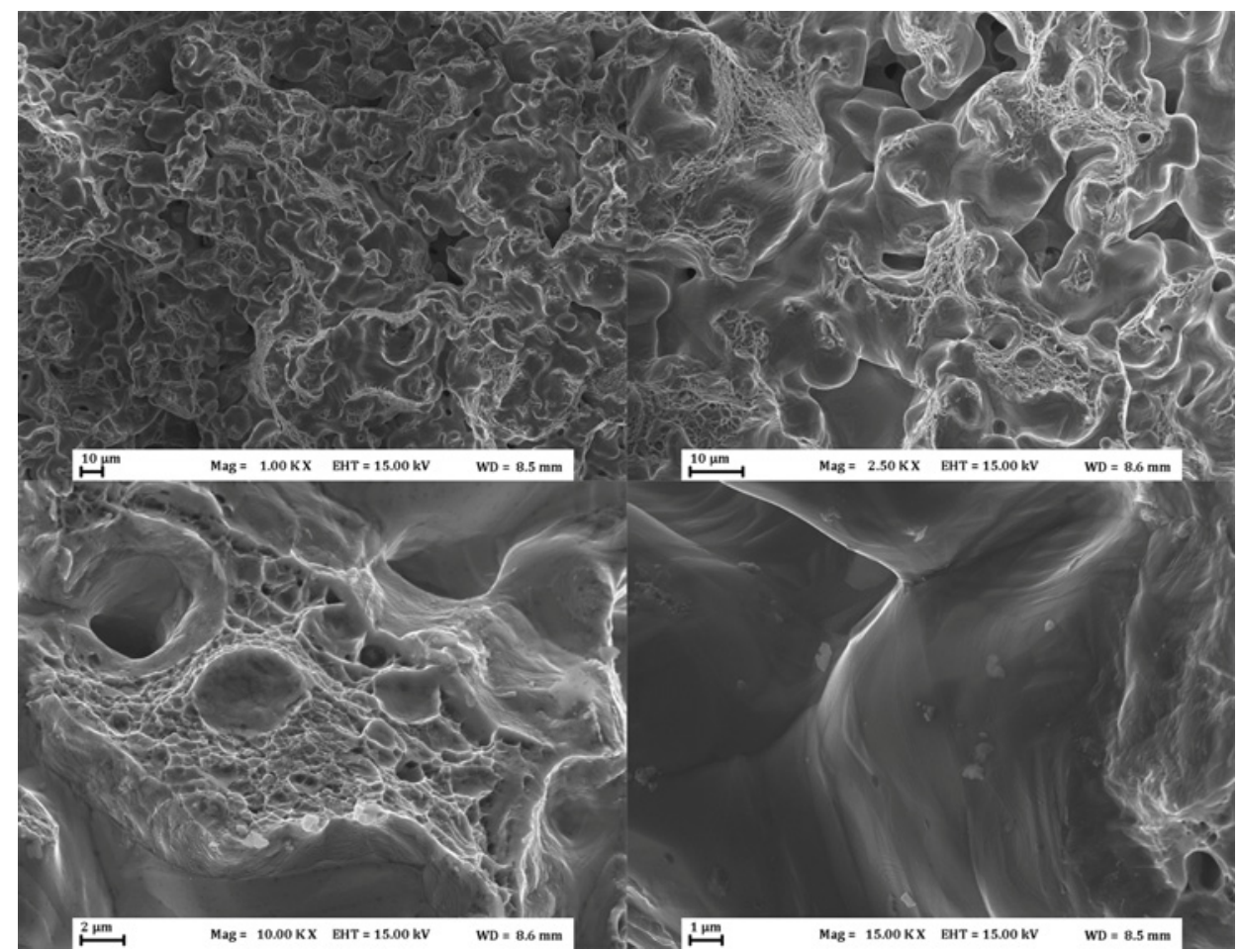

Fig.11. Fracture surface of Distaloy DH material sintered at $1120^{\circ} \mathrm{C}$.

\section{CONCLUSION}

The possibility of manufacturing of valve bridge component for heavy duty engine application utilizing lean prealloyed with $\mathrm{Cr}$ steel powder in combination with novel vacuum sintering and low pressure carburising was confirmed as an attractive alternative. Astaloy CrA material showed the same and even better performance in high cycle fatigue test as currently used cast material, and did not break even after $10^{7}$ cycles. Sintering temperature showed no sinificant influence on the fatigue properties. Two other investigated materials - experimental low Cr alloyed PM steel and Distaloy DH - revealed lower fatigue strength compared to the reference material. Fracture surface analysis showed preferentially ductile failure, well developed sintering necks and absence of oxides residue, indicating good sintering in vaccum. Metallographic investigation showed mostly martensitic microstructure for all the materials. Presence of large pores was observed for low $\mathrm{Cr}$ alloyed and Distaloy DH materials, which can explain lower fatigue strength ot these materials.

\section{Acknowledgement}

Funding from the Swedish Agency for Innovation Systems (VINNOVA) in the frame of the project No: 2014-00795 is greatly acknowledged. Support from the Chalmers Areas of Advance in Production as well as funding from the strategic innovation program LIGHTer, provided by Vinnova, are gratefully acknowledged. 


\section{REFERENCES}

[1] Karamchedu S., Hryha E., Nyborg L.: J. Mater. Process. Technol., vol. 223, 2015, p.171.

[2] Danninger H., Xu C., Khatibi G., Weiss B, Lindqvist B.: Powder Metall., vol. 55, 2013, p. 378.

[3] Bidulsky R., Actis Grande M., Dudrova E., Kabatova M., Bidulska J., Powder Metall., vol. 59, 2016, p. 121.

[4] Danninger H., Sohar C., Gierl C., Betzwar-Kotas A., Weiss B.: Mater. Sci. Forum, vol. 672, 2011, p. 23.

[5] Kupkova M. et al.: Arch. Metall. Mater., vol. 60, 2015, p. 639.

[6] Karamchedu S.: "Critical Aspects of Delubrication and Sintering of Chromium-alloyed Powder Metallurgy Steels”, PhD Thesis, Chalmers University of Technology, Gothenburg, Sweden, 2015.

[7] Berg S.: Adv. Powder. Metall. Part. Mater., vol. 5, 2001, p. 5.

[8] Hryha E., Dudrova E., Bengtsson S.: Powder Metall., vol. 5, 2007, p. 3.

[9] Delarbre P., Schoppa A., Hornof B.: Met. Powder Rep., vol. 71, 2016, p. 344.

[10] Torralba J. M., Esteban L., Bernardo E., Campos M.: Powder Metall., vol. 57, 2014, p. 357.

[11] Mousavinasab S., Blais C.: Mater. Sci. Eng. A, vol. 667, 2016, p. 444.

[12] Azadbeh M., Mohammadzadeh A., Danninger H., Gierl-Mayer C.: Metall. Mater. Trans. B, vol. 46B, 2015, p. 1471.

[13] Dahlström M.: Advances in Powder Metallurgy and Particulate Materials - 2014, Proceedings of the 2014 World Congress on Powder Metallurgy and Particulate Materials, PM 2014, p. 660. 